\title{
MEASUREMENT AND COMPARISON NUTRITION KNOWLEDGE LEVEL OF JUDO ATHLETES ${ }^{(1)}$
}

\section{JUDO SPORCULARININ BESLENME BILGISI DÜZEYLERININ ÖLÇÜLMESI VE KARŞILAŞTIRILMASI}

\author{
Hayrettin GÜMÜŞDA $\breve{G}^{1}$, Alpaslan KARTAL ${ }^{2}$ \\ ${ }^{1-2}$ Yozgat Bozok University, School of Physical Education and Sports, Yozgat / Turkey
}

ORCID ID: 0000-0002-1616-8671 ${ }^{1}, 0000-0003-1567-6276^{2}$

Öz: Amaç: Bu çalışmanın amacı; sporcuların sporcu beslenmesi bilgi düzeylerini saptamak, cinsiyetler arası karşılaştırmalar yapmak, spor yapma süreleri, ekonomik durumlarının bilgi düzeylerine oranlarını belirlenmesi esas alınmış, besin maddeleri, sivı maddeler, toparlanma (yenileme), kilo kontrolü, kilo alımı, kilo kaybı, gıda takviyeleri ile ilgili bilgi düzeylerinin tespiti ve karşılaştırmaları yapılmıştır. Yöntem: Bu çalışmamızda 'sporcu beslenmesi bilgi düzeyi' anketi 'Qustionnaire psychometricalvalid and reliable and suitable for use in sporting groups (Zinn, Scofield\&Wall) uygulanmıştır. Araştırmamız 2017 yllında Sivas, Edirne ve Konya illerinde rastgele seçilen 66 profesyonel sporculara anket uygulaması ile yapılmıştır. İstatiksel hesaplamalarda IBM-SPSS 20 programı kullanılmıs, verilere T testi ve Anova testi uygulanmıștır. Uygulanan testlerin Normallik dağılımı, Parametrik Anova uygulaması, Nonparametrik uygulaması yapılmıştır. Bulgular: Judo sporu yapan kadın ve erkek öğrencilerin toplam besin maddeleri, toplam sivı maddeleri, toplam yenileme (toparlanma), toplam kilo kontrolü, toplam gıda takviyeleri ve tüm toplam puan karşılaştırıldığında farklılık önemsiz bulunmuştur $(P>0,05)$. Gelir düzeyine göre toplam besin maddeleri, toplam sivi maddeleri, toplam kilo kontrol, toplam gida takviyeleri ve tüm toplam puanları karşılaştırıldığında farklılık önemsiz bulunmuştur. Toplam yenilenme yönünden farkl1lık önemli bulunmustur.(P<0,05) Gelir düzeyine göre puanlar karșılaștırıldığında geliri yüksek olanların yenileme puanı yüksektir. Sonuç: Yapılan araştırmada basketbolcular sporcu beslenmesi konusundaki bilgilerinin yeterli olduğu belirlenmiştir.

Anahtar Kelimeler: Spor, Beslenme, Sporcu Beslenmesi, Judo
Abstract: Aim: The aim of this study was to determine nutrition knowledge of athletes athletes, to make comparisons between the Sexes, the time to do sports, Economic rate determination on the basis of their level of knowledge of the situation, nutrients, liquid ingredients, the recovery (renew), weight control, weight gain, weight loss, and comparisons were made determination of the level of knowledge about food supplements. Methods: In this study, the 'athlete nutrition information level' questionnaire was administered to 'Qustionnaire psychometricalvalid and reliable and suitable for use in sporting groups (Zinn, Scofield\&Wall). Our research was conducted in 2017 with a survey application to 66 professional athletes selected randomly in the provinces of $\mathrm{Si}$ vas, Edirne and Konya. The IBM-SPSS 20 program was used for statistical calculations and the T test and ANOVA test were applied to the data. Normality distribution, parametric Anova application, nonparametric application were performed. Results: The difference between total nutrients, total liquids, Total Refreshment (recovery), total weight control, total food supplements and all total scores of male and female students engaged in Judo were found to be insignificant $(P>0.05)$. The difference between total nutrients, total liquid ingredients, total weight control, total food supplements and all total scores by income level was found to be insignificant when compared. The difference in terms of total regeneration was found to be significant.( $(\mathrm{P}<0.05)$ compared to income level scores, those with higher income have higher renewal scores. Conclusion: In the research, it was determined that basketball players have sufficient knowledge about athlete nutrition.

Key Words: Sports, Nutrition, Athlete Nutrition, Judo

Doi: $10.17363 /$ SSTB.2019.33.1

(1) Sorumlu Yazar, Corresponding Author: Hayrettin GÜMÜŞDAĞ “Prof. Dr., Professor”, Yozgat Bozok University, School of Physical Education and Sports, Yozgat / Turkey, hgumusdag06@hotmail.com, Geliş Tarihi / Received: 13.07.2019, Kabul Tarihi / Accepted: 22.12.2019, Makalenin Türü: Type of Article: (Araştırma - Uygulama; Research-Application) Çıkar Çatı̧ması, Yok - Conflict of Interest, No, Etik Kurul Raporu veya Kurum İzin Bilgisi- Ethical Board Report or Institutiunal Approval, Yok/No 
International Refereed Academic Journal of Sports, Health and Medical Sciences

October - November - December Issue: 33 Fall Winter Semester Year: 2019

Uluslararası Hakemli Akademik Spor Sağlık ve Tıp Bilimleri Dergisi

Ekim - Kasım - Aralık Sayı: 33 Güz Kış Dönemi Yıl: 2019 ID:473 K:459

ISSN Print: 2146-8508 Online 2147-1711

(ISO 18001-OH-0090-13001706 / ISO 14001-EM-0090-13001706 / ISO 9001-QM-0090-13001706 / ISO 10002-CM-0090-13001706) (TRADEMARK)

(2015/04315- 2015-GE-18972)

\section{INTRODUCTION}

The physical movements that began with the first human East continued throughout man's life. In time, people felt the need to live in a community, and because of the responsibilities of living in a community, they had to develop their physical activities in a multifaceted way. Judo is an art with a sporting side, a branch of philosophy. It whips up feelings of body, intelligence and morality. Judo can also be described as a branch of knowledge of the art of unarmed combat that teaches the way in which the weak defeat the strong. Therefore, training and teaching methods should not be viewed as simple actions. Both the changes in the world and the developments in science and technique reflected the principles of technique, tactics and training in judo and led to the formation of judo in today's modern sense. In sport, the center of gravity is important. The center of gravity is the point at which the weight, which can rotate freely around the body, is equal in all kinds of opposite directions, and where the coordinate planes intersect. According to the center of gravity branches, the athlete gives advantage and disadvantage. In high jump, the higher the athlete's center of gravity, the more successful it is. In wrestlers and judoists, the fact that the center of gravity is close to the ground means that the balance is solid, and that is an advantage. A variety of body composition re- search is being done and methods are being developed. What should be the amount of fat and fat content in the body for both sedanters and athletes? his question has been the subject of research. Many views and conclusions have been put forward on this issue. "In general, the daily energy needs of Sports users vary according to age, gender, body weight, physical condition, place of sport, economic situation and sports branches (Güneş 2005).

The aim of this study is to determine the nutritional levels of the athletes active in Judo.

\section{LITERATURE REVIEW}

Nutrition: to meet the energy needs of the vital activities in our body, protect our health, physical growth and development to make it possible to practice and adapt your workout to maximize the effects of essential nutrients; carbohydrates, fats, proteins, vitamins, minerals and water can be defined as consuming a balanced diet (Zorba, 2001).

Athlete nutrition: according to the sex of the athlete, age, daily physical activities and the type of sport he does, training and competition periods by making arrangements for food intake in an adequate and balanced manner (Güneş, 2009). Nutrition support products: all kinds of training techniques, mechanical devices, nutritional support, paralogic support or physiologic technical ergogenic aid which aim to increase exercise performance 
International Refereed Academic Journal of Sports, Health and Medical Sciences October - November - December Issue: 33 Fall Winter Semester Year: 2019

Uluslararası Hakemli Akademik Spor Sağlık ve Tıp Bilimleri Dergisi Ekim - Kasım - Aralık Sayı: 33 Güz Kış Dönemi Yıl: 2019 ID:473 K:459

ISSN Print: 2146-8508 Online 2147-1711

(ISO 18001-OH-0090-13001706 / ISO 14001-EM-0090-13001706 / ISO 9001-QM-0090-13001706 / ISO 10002-CM-0090-13001706) (TRADEMARK)

and adaptation to training. These aids are effective in preparing the individual for exercise, increasing the efficiency of exercise, or increasing post-exercise recovery (Kreider et all, 2004).

\section{Athletes ' energy and nutrient require- ments}

Ensuring performance in sport is possible with a balanced diet. For a balanced diet, 55$60 \%$ of the total energy should be provided from carbohydrates, $10-12 \%$ from proteins, $25-30 \%$ from fats (A.D.A, 2009).

All kinds of chemical substances needed by the body that provide heat and energy, which have the task of making and renewing tissues and regulating the life process are called "food items" (Muratl1, 2007). Studies to date have shown that human beings need more than 50 types of food elements in order to sustain their growth, development and healthy lives (Baysal, 2010).

Energy can be defined as the capacity to do a job in general. Our body needs energy in every event from jogging to breathing to even digestion of nutrients. Muscle contraction can only be achieved by the release of energy. Nov. Food is indirect sources of energy. The potential energy in food (carbohydrates, fats, proteins) is synthesized from adenosine tri phosphate (ATP) through a series of chemical reactions called metabolic functions, ATP is the direct source of energy

Energy formation by aerobic means: in the presence of $\mathrm{O} 2$ by aerobic system, ATP is synthesized as a result of burning carbohydrates, fats and proteins. This energy system, which has the highest capacity, is used as the main energy source for long-term, low-intensity exercises, for example, in sports such as marathons, skiing, and football. Energy generation by anaerobic means: it is the energy system that acts most quickly. Creatine phosphate (CP) and glycogen are destroyed in an oxygen-free environment and provide energy. In this way,

\section{Alactic Anaerobic System (ATP-CP):} for muscle contraction in oxygen-free environment, ATP and CP, which are stored in the muscle, albeit in a small amount, are used Nov. These molecules have the power to release very high energy in a short time. High intensity (8-10 SEC. short-term exertions constitute the main energy source of the organism.

2. Lactic Anaerobic System: 8-10 SEC in organism due to rapid depletion of energy obtained from Alactic system. with a few minutes of effort (200-400, $800 \mathrm{~m}$ runs, $100 \mathrm{~m}$ swimming etc.) a large part of the energy needed is provided by the burning of glycogen in an oxygen-free envi- 
International Refereed Academic Journal of Sports, Health and Medical Sciences

October - November - December Issue: 33 Fall Winter Semester Year: 2019

Uluslararası Hakemli Akademik Spor Sağlık ve Tıp Bilimleri Dergisi

Ekim - Kasım - Aralık Sayı: 33 Güz Kış Dönemi Yıl: 2019 ID:473 K:459

ISSN Print: 2146-8508 Online 2147-1711

(ISO 18001-OH-0090-13001706 / ISO 14001-EM-0090-13001706 / ISO 9001-QM-0090-13001706 / ISO 10002-CM-0090-13001706) (TRADEMARK)

ronment (glycolysis). One of the major disadvantages of this system is that lactic acid produced as a result of glycolysis accumulates in novices and blood, causing fatigue.

During exercise, all three systems contribute to ATP production. But which system will play a more important role depends on the type of exercise (Ersoy, 2011).

\section{Essential Nutrients}

There are essential nutrients that the human body needs, consisting of organic and inorganic elements. Carbohydrates, fats, proteins, vitamins, minerals and water are the elements that make up the body's chemical composition. The average ratio in an adult is $59 \%$ water, $18 \%$ protein, $18 \%$ fat, $4.3 \%$ minerals and $0.7 \%$ carbohydrates. The first three of these are used as fuel sources and are taken in exchange for our daily energy needs. Vitamins, minerals and water have no energy value. But it is necessary to maintain adequate body functions and health (Baysal, 2005; Sun, 2005).

\section{Carbohydrates}

Carbohydrates are organic compounds composed of carbon, hydrogen and oxygen molecules in human and animal tissues (Pehlivan, 2005).Carbohydrates consisting of carbon and hydrogen are the main energy source in training and account for $60 \%$ of daily calorie needs (Yildirim et al., 2005).

Carbohydrates (Cho) are studied in two groups, simple and complex. In terms of athletic performance, healthy nutrition and daily consumption of carbohydrates to $85 \%$ of a compound carbohydrate-containing foods (whole grains, vegetables, and dry beans fall into this category), however, $15 \%$ of foods that contain simple carbohydrates (sugars and sugar derivatives, sugar-containing beverages, honey, jam, etc.) should occur. Because the digestion of compound carbohydrates takes longer than simple sugars (3-4 hours), their effects on blood sugar are slower and last longer. Simple carbohydrates for 15 minutes without much change in the small intestine. they pass directly into the blood in a short period of time (Güneş, 2009; Paker, 1996; Pehlivan, 2005).

\section{Proteins}

Proteins with carbon, hydrogen, oxygen and nitrogen in their structures are essential organic compounds for Life (Sun, 2009). The tasks of proteins for body work include; 1. Novelties are the building blocks of other tissues and enzymes. 2nd ed. It provides growth and development. 3. It is responsible for tissue construction and repair. 4. The blood protein is responsible for the production of 
International Refereed Academic Journal of Sports, Health and Medical Sciences October - November - December Issue: 33 Fall Winter Semester Year: 2019

Uluslararası Hakemli Akademik Spor Sağlık ve Tıp Bilimleri Dergisi

Ekim - Kasım - Aralık Sayı: 33 Güz Kış Dönemi Yıl: 2019 ID:473 K:459

ISSN Print: 2146-8508 Online 2147-1711

(ISO 18001-OH-0090-13001706 / ISO 14001-EM-0090-13001706 / ISO 9001-QM-0090-13001706 / ISO 10002-CM-0090-13001706) (TRADEMARK)

(2015/04315- 2015-GE-18972)

hemoglobin and hormones. (Ersoy, 2004; Yilmaz, 2002).

Proteins, enzymes and hormones are also required for the construction of connective tissue and for the repair of micro-damage to muscles during exercise. The protein requirement for athletes is $1,2-2.0 \mathrm{~g} / \mathrm{kg}$. Protein needs can be met with an adequate diet (Cotugna et all, 2005). Regular and intensive exercises increase protein requirements and naturally increase nutrient intake (Ersoy, 2007).

\section{Fats}

Short-term (up to 45 seconds up to two minutes) and medium term (from two minutes up to eight minutes) endurance in sports activities that require mixed carbohydrates and fats, long-term (over one hour) oil is used as the main energy source in sporting activities (Y1lmaz, 2002).

\section{Vitamins}

Vitamins serve as a kind of engine for most enzymes that are the controllers of intracellular chemical events. The human body does not have the ability to synthesize vitamins. Therefore, vitamins must be taken through foods (Yilmaz, 2002).

\section{Minerals}

Minerals do not contain calories from foodstuffs, such as water and vitamins. But they are of great importance for most normal cellular functions in the contraction of muscles, in the heartbeat, in the protection of the health of teeth and bones (Muratl1, 2007; Gürsoy and Dane, 2002).

\section{Liquid Consumption}

Water is an essential and unique nutrient. Water controls and protects the physiological distribution in the cells and the various water compartments in our body (cell, intravenous and non-vascular). In addition, Water maintains the physiological functions of cells and organs (heart, muscles, blood vessels, kidneys, gastrointestinal system) (Ustdal ve Koker, 1998).

\section{Training or competition diet}

The difference between the athlete's diet and other diets is that athletes consume the fluid they lose through sweat and energy due to increased physical activity in addition to the diet. Additional energy needs must be provided from carbohydrates. In some cases, the need for protein, B complex vitamins is increasing. However, consuming a diet that meets the energy requirement can also meet the increasing need for these nutrients. As the energy requirement increases, 2 food groups rich in carbohydrates (grain, vegetable-fruit group) should be increased portion amounts of foods. With this increase, most athletes are unable to meet their energy requirements. In 


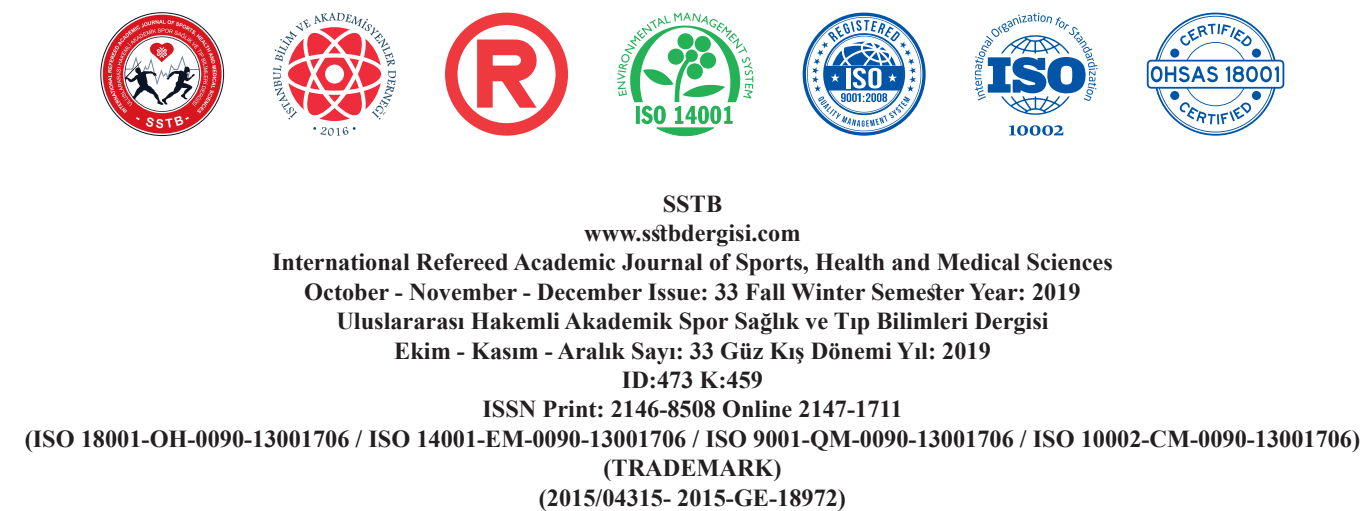

(2015/04315- 2015-GE-18972)

order to increase dietary diversity, portions of milk and protein-rich food should also be increased, thus increasing energy requirements should be provided from various food groups. Another important issue for athletes is the time of consumption of meals and Dec meals. Consumption of food and fluids is associated with the intensity of exercise as well as the athlete's personal characteristics. For example, an athlete may tolerate milk and one sandwich 1 hour before a light workout, while consuming the same foods and drinks before an exercise. Judoists should determine their daily calorie consumption by considering their body weight, training needs and weight status (USA Weightlifting may be uncomfortable. Athletes should consume 3 main 3 Dec meals as little as often as they can (Ersoy 2011)). Forty to sixty percent of a judo's total calories must come from carbohydrates, based on the type and intensity of training. Carbohydrate intake recommendations range from five to twelve grams for each kilogram of body weight. This December represents the type, duration and intensity of an activity requiring carbohydrate energy that an individual participates in. For athletes who need excessive carbohydrate energy and glycogen storage, a large intake of carbohydrates is crucial for optimal sports performance (USA Weightlifting Federation 2013).
Considering that Judon represents high intensity interval activity, it is clear that proper Cho consumption is important for high quality training (Saunders et al 2004).

Eating habits affect the athlete's performance. A variety of factors, including the proper energy diet, macronutrient distribution and adequate vitamin mineral supplements, should be considered for the nutrition plan. The diet of athletes should also be determined according to their individual needs, frequency, intensity and duration of exercise (American Dietetic Association, Dietitians of Canada, and the American College of Sports Medicine 2009).

Judo is one of the main sports where nutritional deficiencies are reflected in performance. Low calorie intake from food leads to loss of novelties, menstrual disorder, increased sense of fatigue and ultimately reduced athlete performance (Ainsworth et al 2000).

Many athletes spend most of their time in intensive training and competitions without taking due care to minimize the negative impact of food restriction on their performance (Hall and Lane 2001).

Low calorie intake will restrict athletes from achieving performance goals. It is known that there is a significant relationship between the level of knowledge on nutrition and malnutrition habits (Burke 1995). 
International Refereed Academic Journal of Sports, Health and Medical Sciences October - November - December Issue: 33 Fall Winter Semester Year: 2019

Uluslararası Hakemli Akademik Spor Sağlık ve Tıp Bilimleri Dergisi

Ekim - Kasım - Aralık Sayı: 33 Güz Kış Dönemi Yıl: 2019 ID:473 K:459

ISSN Print: 2146-8508 Online 2147-1711

(ISO 18001-OH-0090-13001706 / ISO 14001-EM-0090-13001706 / ISO 9001-QM-0090-13001706 / ISO 10002-CM-0090-13001706) (TRADEMARK)

\section{MATERIAL and METHOD}

\section{Research Group}

A total of 66 athletes, 41 men and 25 women ,from the Judo National Team participated in the study in 2017 and from the judo participants in the preparation camp in the provinces of Sivas,Edirne and Konya, participated as volunteers. The athletes involved in the research are athletes who are active in the sport of Judo.

\section{Data Collection Tools}

In order to collect data in the study, the 'athlete nutrition information level questionnaire 'developed at' Qstionnaire psychometrical valid and reliable and suitable for use in sporting groups ' (Zinn,Scofield\&Wall, 2005) was applied. 2 likert scale, 3 likert scale , 4 likert scale, 5 likert scale were applied in the re- search scan model. The scale is arranged as $1=$ High, $2=$ low, $3=$ not sure, multiple choice.

\section{Data Collection}

All data contained in the study were collected from athletes who actively engaged in Judo during the 2017 season. Questionnaires were hand-delivered to athletes and hand-delivered upon completion.filling the scales took about 25 minutes for an athlete.

\section{Analysis Of The Data}

After descriptive statistical operations (mean, standard deviation, frequency and (\%) ) were applied to the obtained data, Independent ttest and ANOVA test were used to determine the nutritional information levels of the athletes. 
SSTB

www.sstbdergisi.com

International Refereed Academic Journal of Sports, Health and Medical Sciences

October - November - December Issue: 33 Fall Winter Semester Year: 2019

Uluslararası Hakemli Akademik Spor Sağlık ve Tıp Bilimleri Dergisi

Ekim - Kasım - Aralık Sayı: 33 Güz Kıș Dönemi Yıl: 2019 ID:473 K:459

ISSN Print: 2146-8508 Online 2147-1711

(ISO 18001-OH-0090-13001706 / ISO 14001-EM-0090-13001706 / ISO 9001-QM-0090-13001706 / ISO 10002-CM-0090-13001706) (TRADEMARK)

(2015/04315- 2015-GE-18972)

\section{FINDINGS}

Findings on differences between athletes ' nutritional scores and gender variable;

Table 1. Comparison of Nutrition Scores of Individuals by Gender

\begin{tabular}{|c|c|c|c|c|c|c|}
\hline QUANTITY & GENDER & & $\mathrm{N}$ & Mean & Std. Deviation & Result \\
\hline \multirow{2}{*}{ TOTAL NUTRITION } & \multirow[t]{2}{*}{ dimension1 } & WOMAN & 26 & 35,3077 & 6,76325 & $\mathrm{t}=0,78$ \\
\hline & & MAN & 40 & 36,4750 & 5,30596 & $\mathrm{P}=0,437$ \\
\hline \multirow{2}{*}{ TOTAL FLUID } & \multirow[t]{2}{*}{ dimension 1} & WOMAN & 26 & 6,9231 & 1,74179 & $\mathrm{t}=0,25$ \\
\hline & & MAN & 40 & 7,0250 & 1,44093 & $\mathrm{P}=0,797$ \\
\hline \multirow{2}{*}{ TOTAL REGENARATION } & \multirow[t]{2}{*}{ dimension1 } & WOMAN & 26 & 8,8462 & 2,66372 & $\mathrm{t}=0,41$ \\
\hline & & MAN & 40 & 8,5500 & 2,95218 & $\mathrm{P}=0,681$ \\
\hline \multirow{2}{*}{$\begin{array}{l}\text { TOTAL WEIGHT CONT- } \\
\text { ROL }\end{array}$} & \multirow[t]{2}{*}{ dimension1 } & WOMAN & 26 & 12,0769 & 3,14863 & $\mathrm{t}=0,28$ \\
\hline & & MAN & 40 & 12,3000 & 3,02299 & $\mathrm{P}=0,774$ \\
\hline \multirow{2}{*}{$\begin{array}{l}\text { TOTAL FOOD SUPLE- } \\
\text { MENT }\end{array}$} & \multirow[t]{2}{*}{ dimension 1} & WOMAN & 26 & 7,5000 & 3,10161 & $\mathrm{t}=0,55$ \\
\hline & & MAN & 40 & 7,9250 & 2,99048 & $\mathrm{P}=0,580$ \\
\hline \multirow[t]{2}{*}{ SUM } & dimension 1 & WOMAN & 26 & 70,5769 & 15,43029 & $\mathrm{t}=0,47$ \\
\hline & & MAN & 40 & 72,2750 & 13,61370 & $\mathrm{P}=0,640$ \\
\hline
\end{tabular}

There was no statistically significant difference between the total nutrients, total fluids, Total Refreshment, total weight control, total food supplements and all total scores of the boys and girls who played Judo $(\mathrm{P}>0.05)$.

Findings on differences between athletes ' nutrition scores and learning status variable; 
SSTB

www.sstbdergisi.com

International Refereed Academic Journal of Sports, Health and Medical Sciences

October - November - December Issue: 33 Fall Winter Semester Year: 2019

Uluslararası Hakemli Akademik Spor Sağlık ve Tıp Bilimleri Dergisi

Ekim - Kasım - Aralık Sayı: 33 Güz Kış Dönemi Yıl: 2019 ID:473 K:459

ISSN Print: 2146-8508 Online 2147-1711

(ISO 18001-OH-0090-13001706 / ISO 14001-EM-0090-13001706 / ISO 9001-QM-0090-13001706 / ISO 10002-CM-0090-13001706) (TRADEMARK)

(2015/04315- 2015-GE-18972)

Table 2. Comparison of Nutrition Scores of Individuals According to Educational Status

\begin{tabular}{|c|c|c|c|c|c|}
\hline QUANTITY & \multicolumn{2}{|c|}{ EDUCATION } & $\mathrm{N}$ & Mean & Std. Deviation \\
\hline \multirow{2}{*}{ TOTAL NUTRITION } & \multirow[t]{2}{*}{ dimension 1} & UNDERGRADUATE & 64 & 36,1406 & 5,77589 \\
\hline & & GRADUATE & 2 & 32,0000 & 11,31371 \\
\hline \multirow{2}{*}{ TOTAL FLUID } & \multirow[t]{2}{*}{ dimension 1} & UNDERGRADUATE & 64 & 7,0625 & 1,37869 \\
\hline & & GRADUATE & 2 & 4,5000 & 4,94975 \\
\hline \multirow{2}{*}{ TOTAL REGENARATION } & \multirow[t]{2}{*}{ dimension 1} & UNDERGRADUATE & 64 & 8,7344 & 2,84098 \\
\hline & & GRADUATE & 2 & 6,5000 & ,70711 \\
\hline \multirow{2}{*}{ TOTAL WEIGHT CONTROL } & \multirow[t]{2}{*}{ dimension 1} & UNDERGRADUATE & 64 & 12,3125 & 3,02306 \\
\hline & & GRADUATE & 2 & 9,0000 & 2,82843 \\
\hline \multirow{2}{*}{ TOTAL FOOD SUPLEMENT } & \multirow[t]{2}{*}{ dimension 1} & UNDERGRADUATE & 64 & 7,8281 & 2,93071 \\
\hline & & GRADUATE & 2 & 5,5000 & 6,36396 \\
\hline \multirow[t]{2}{*}{ SUM } & dimension 1 & UNDERGRADUATE & 64 & 72,0469 & 13,91748 \\
\hline & & GRADUATE & 2 & 57,5000 & 24,74874 \\
\hline
\end{tabular}

In order to make a statistical assessment, the number of subjects in the groups must be more than 3 and 3. In this study, a statistical encoun- ter cannot be done because there are 2 individuals above the language.

Differences between athletes " nutritional scores and income level variable; 
SSTB

www.sstbdergisi.com

International Refereed Academic Journal of Sports, Health and Medical Sciences October - November - December Issue: 33 Fall Winter Semester Year: 2019

Uluslararası Hakemli Akademik Spor Sağlık ve Tıp Bilimleri Dergisi Ekim - Kasım - Aralık Sayı: 33 Güz Kıs Dönemi Yıl: 2019 ID:473 K:459

ISSN Print: 2146-8508 Online 2147-1711

(ISO 18001-OH-0090-13001706 / ISO 14001-EM-0090-13001706 / ISO 9001-QM-0090-13001706 / ISO 10002-CM-0090-13001706) (TRADEMARK)

(2015/04315- 2015-GE-18972)

Table 3. Comparison of Nutrition Scores of Individuals by Income Level

\begin{tabular}{llllll}
\multicolumn{2}{c}{ INCOME } & $\mathrm{N}$ & Mean & Std. Deviation & Result \\
\hline TOTAL NUT- & $\begin{array}{l}2001-3000 \\
\text { RITION }\end{array}$ & 9 & 33,6667 & 9,06918 & $\mathrm{~F}=1,31$ \\
\cline { 2 - 6 } & $3001-4000$ & 42 & 36,0238 & 5,38511 & $\mathrm{P}=0,329$ \\
\cline { 2 - 6 } & $4001-5000$ & 15 & 37,4000 & 4,91063 & \\
\cline { 2 - 6 } & Total & 66 & 36,0152 & 5,90044 & $\mathrm{~F}=1,31$ \\
\hline TOTAL FLUID & $2001-3000$ & 9 & 6,4444 & 1,66667 & $\mathrm{P}=0,329$ \\
\cline { 2 - 6 } & $3001-4000$ & 42 & 6,9524 & 1,51339 & \\
\hline
\end{tabular}

\begin{tabular}{llllll}
\hline TOTAL REGE- & $2001-3000$ & 9 & 6,8889 & 2,66667 & $\mathrm{~F}=1,31$ \\
\cline { 2 - 6 } NARATION & $3001-4000$ & 42 & 8,4286 & 2,95613 & $\mathrm{P}=0,329$ \\
\cline { 2 - 6 } & $4001-5000$ & 15 & 10,4000 & 1,40408 & \\
\hline
\end{tabular}

\begin{tabular}{|c|c|c|c|c|c|}
\hline \multirow{3}{*}{$\begin{array}{l}\text { TOTAL WE- } \\
\text { IGHT CONT- } \\
\text { ROL }\end{array}$} & 2001-3000 & 9 & 10,6667 & 3,35410 & $\mathrm{~F}=1,31$ \\
\hline & $3001-4000$ & 42 & 12,0952 & 2,98622 & $\mathrm{P}=0,329$ \\
\hline & $4001-5000$ & 15 & 13,4667 & 2,72204 & \\
\hline \multirow{3}{*}{$\begin{array}{l}\text { TOTAL FOOD } \\
\text { SUPLEMENT }\end{array}$} & 2001-3000 & 9 & 6,5556 & 3,32081 & $\mathrm{~F}=1,31$ \\
\hline & $3001-4000$ & 42 & 7,6429 & 3,03493 & $\mathrm{P}=0,329$ \\
\hline & $4001-5000$ & 15 & 8,8000 & 2,62406 & \\
\hline \multirow[t]{3}{*}{ SUM } & $\begin{array}{l}\text { 2000VEAL- } \\
\text { TI }\end{array}$ & 9 & 64,2222 & 16,58899 & $\mathrm{~F}=1,31$ \\
\hline & $3001-4000$ & 42 & 71,0952 & 13,84374 & $\mathrm{P}=0,329$ \\
\hline & $4001-5000$ & 15 & 77,4667 & 12,39163 & \\
\hline
\end{tabular}

The difference between total nutrients, total income level was found to be insignificant liquid ingredients, total weight control, to- when compared. The difference in terms of tal food supplements and all total scores by total regeneration was found to be significant. 
International Refereed Academic Journal of Sports, Health and Medical Sciences October - November - December Issue: 33 Fall Winter Semester Year: 2019

Uluslararası Hakemli Akademik Spor Sağlık ve Tıp Bilimleri Dergisi Ekim - Kasım - Aralık Sayı: 33 Güz Kış Dönemi Yıl: 2019 ID:473 K:459

ISSN Print: 2146-8508 Online 2147-1711

(ISO 18001-OH-0090-13001706 / ISO 14001-EM-0090-13001706 / ISO 9001-QM-0090-13001706 / ISO 10002-CM-0090-13001706) (TRADEMARK)

(2015/04315- 2015-GE-18972)

$(\mathrm{P}<0.05)$ compared to income level, scores were significant between $2001-3000$ and 4001-5000. Accordingly, those with high income have a high renewal score.

Note: in this evaluation, 2 people with income below 1000 were included in the 2001-3000 group, and 2 people with income above 5000 were included in the 4500 group. Because there are 2 individuals, statistical analysis cannot be done.

Findings on differences between athletes ' nutritional scores and the league variable they participated in;

Table 4. Comparison of Nutrition Scores of Individuals According to the League They

\section{Participated in}

Group Statistics

\begin{tabular}{|c|c|c|c|c|c|c|}
\hline & LEAGUE & & $\mathrm{N}$ & Mean & Std. Deviation & Result \\
\hline \multirow{2}{*}{$\begin{array}{l}\text { TOTAL NUT- } \\
\text { RITION }\end{array}$} & dimension1 & 1,00 & 56 & 37,6786 & 4,00503 & $\mathrm{t}=5,29$ \\
\hline & & 2,00 & 9 & 26,0000 & 6,26498 & $\mathrm{P}=0,001^{*}$ \\
\hline \multirow[t]{2}{*}{ TOTAL FLUID } & dimension1 & 1,00 & 56 & 7,3036 & 1,21983 & $\mathrm{t}=4,44$ \\
\hline & & 2,00 & 9 & 5,1111 & 2,14735 & $\mathrm{P}=0,001 *$ \\
\hline \multirow{2}{*}{$\begin{array}{l}\text { TOTAL REGE- } \\
\text { NARATION }\end{array}$} & dimension 1 & 1,00 & 56 & 9,0357 & 2,77629 & $\mathrm{t}=2,21$ \\
\hline & & 2,00 & 9 & 6,8889 & 2,14735 & $\mathrm{P}=0,003 *$ \\
\hline \multirow{2}{*}{$\begin{array}{l}\text { TOTAL WE- } \\
\text { IGHT CONT- } \\
\text { ROL }\end{array}$} & dimension 1 & 1,00 & 56 & 12,8393 & 2,70875 & $\mathrm{t}=4,30$ \\
\hline & & 2,00 & 9 & 8,6667 & 2,64575 & $\mathrm{P}=0,001 *$ \\
\hline \multirow{2}{*}{$\begin{array}{l}\text { TOTAL FOOD } \\
\text { SUPLEMENT }\end{array}$} & dimension 1 & 1,00 & 56 & 8,4643 & 2,52957 & $\mathrm{t}=5,01$ \\
\hline & & 2,00 & 9 & 3,8889 & 2,61937 & $\mathrm{P}=0,001 *$ \\
\hline \multirow[t]{2}{*}{ SUM } & dimension 1 & 1,00 & 56 & 75,3036 & 11,04523 & $\mathrm{t}=6,05$ \\
\hline & & 2,00 & 9 & 50,5556 & 13,47322 & $\mathrm{P}=0,001 *$ \\
\hline
\end{tabular}

$* \mathrm{p}<0,05$

Since all individuals in the study were national athletes, no comparison was made. 
International Refereed Academic Journal of Sports, Health and Medical Sciences

October - November - December Issue: 33 Fall Winter Semester Year: 2019

Uluslararası Hakemli Akademik Spor Sağlık ve Tıp Bilimleri Dergisi

Ekim - Kasım - Aralık Sayı: 33 Güz Kış Dönemi Yıl: 2019 ID:473 K:459

ISSN Print: 2146-8508 Online 2147-1711

(ISO 18001-OH-0090-13001706 / ISO 14001-EM-0090-13001706 / ISO 9001-QM-0090-13001706 / ISO 10002-CM-0090-13001706) (TRADEMARK)

(2015/04315- 2015-GE-18972)

Table 5. Comparison of correlation coefficients between total nutrients and total liquids, total renewal, total weight control, total food supplements

BMI

\begin{tabular}{lllllll}
$\mathrm{R}$ &, 144 &,- 008 &, 181 &, 148 &, 125 &, 152 \\
\hline $\mathrm{P}$ &, 253 &, 950 &, 149 &, 240 &, 321 &, 228 \\
\hline
\end{tabular}

There was no statistically significant difference between total nutrients and total fluids, Total Refreshment, total weight control, total

Findings on differences between athletes ' nutritional scores and their year of sport;

Table 6. Comparison of Nutrition Scores of Individuals by Year of Sport

\begin{tabular}{|c|c|c|c|c|c|c|c|}
\hline & & $\begin{array}{l}\text { TOTAL } \\
\text { NUTRITI- } \\
\text { ON }\end{array}$ & $\begin{array}{l}\text { TOTAL } \\
\text { FLUID }\end{array}$ & $\begin{array}{l}\text { TOTAL REGE- } \\
\text { NARATION }\end{array}$ & $\begin{array}{l}\text { TOTAL } \\
\text { WEIGHT } \\
\text { CONTROL }\end{array}$ & $\begin{array}{l}\text { TOTAL FOOD } \\
\text { SUPLEMENT }\end{array}$ & SUM \\
\hline \multirow{2}{*}{$\begin{array}{l}\text { EXPRI- } \\
\text { ENCE }\end{array}$} & $\mathrm{R}$ & ,398 &, 352 &, $345^{*}$ &, 350 &, 421 &, 435 \\
\hline & $\mathrm{P}$ &, $001 *$ &, $004 *$ &, $005^{*}$ &, $004^{*}$ &, $001 *$ &, $001 *$ \\
\hline
\end{tabular}

$* \mathrm{p}<0,05$

The number of Lecithin cholesterol acyltransferase (LCAT) was found between the duration of sports and total nutrients (r:0.398) (same way) and total fluids (R:0.352) (same way) during sports and total weight control in the same way (R:0.350) and the duration of sports and total total in the same way (R:0.435). This association found LCAT numbers are statistically significant. As the duration of playing sports increases, the scores all increase.

food supplements and the total total correlation coefficients $(\mathrm{p}>0.05)$.

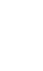


International Refereed Academic Journal of Sports, Health and Medical Sciences October - November - December Issue: 33 Fall Winter Semester Year: 2019

Uluslararası Hakemli Akademik Spor Sağlık ve Tıp Bilimleri Dergisi Ekim - Kasım - Aralık Sayı: 33 Güz Kıș Dönemi Yıl: 2019 ID:473 K:459

ISSN Print: 2146-8508 Online 2147-1711

(ISO 18001-OH-0090-13001706 / ISO 14001-EM-0090-13001706 / ISO 9001-QM-0090-13001706 / ISO 10002-CM-0090-13001706) (TRADEMARK)

Findings on differences between athletes ' nutrition scores and the number of weekly work-

outs;

Table 7. Comparison of Nutrition Scores of Individuals by Number of Weekly Workouts

\begin{tabular}{|c|c|c|c|c|c|c|c|}
\hline & & $\begin{array}{l}\text { TOTAL } \\
\text { NUTRITI- } \\
\text { ON }\end{array}$ & $\begin{array}{l}\text { TO- } \\
\text { TAL } \\
\text { FLU- } \\
\text { ID }\end{array}$ & $\begin{array}{l}\text { TOTAL REGE- } \\
\text { NARATION }\end{array}$ & $\begin{array}{l}\text { T. WEIGHT } \\
\text { CONTROL }\end{array}$ & $\begin{array}{l}\text { T. FOOD } \\
\text { SUPLE- } \\
\text { MENT }\end{array}$ & SUM \\
\hline $\begin{array}{l}\text { HAFTA- } \\
\text { LIK ANT- } \\
\text { REMAN } \\
\text { SAYISI }\end{array}$ & $\mathrm{R}$ & 0,182 & 0,244 & 0,088 & 0,132 & 0,185 & 0,188 \\
\hline & P & 0,147 & 0,052 & 0,488 & 0,294 & 0,139 & 0,133 \\
\hline
\end{tabular}

There was no statistically significant differ- tal fluids, Total Refreshment, total weight conence in the correlation coefficients between trol, total food supplements and the total total the number of training and total nutrients, to- $\quad(p>0.05)$.

Table 8.Correlation Coefficients Between age and Nutritional Scores of Individuals

\begin{tabular}{|c|c|c|c|c|c|c|c|}
\hline & & $\begin{array}{l}\text { TOTAL } \\
\text { NUTRI- } \\
\text { TION }\end{array}$ & $\begin{array}{l}\text { TO- } \\
\text { TAL } \\
\text { FLU- } \\
\text { ID }\end{array}$ & $\begin{array}{l}\text { TOTAL } \\
\text { REGENARA- } \\
\text { TION }\end{array}$ & $\begin{array}{l}\text { T. WEIGHT } \\
\text { CONTROL }\end{array}$ & $\begin{array}{l}\text { T. FOOD } \\
\text { SUPLE- } \\
\text { MENT }\end{array}$ & SUM \\
\hline \multirow[t]{2}{*}{ AGE } & $\mathrm{R}$ & ,430 & ,358 & ,490 & ,508 &, $446^{*}$ & ,510 \\
\hline & $\mathrm{P}$ &, $001 *$ &, $003 *$ &, $001 *$ &, $001 *$ &, $001 *$ &, $001^{*}$ \\
\hline
\end{tabular}

$* \mathrm{p}<0,05$

Same way between age and nutrients (r: 0,430$)$

Same directional between age and liquid materials (r: 0.358)
Same-way $(\mathrm{r}: 0,490)$ between age and total renewal)

Same way between age and total weight control (r: 0,505) 
International Refereed Academic Journal of Sports, Health and Medical Sciences

October - November - December Issue: 33 Fall Winter Semester Year: 2019

Uluslararası Hakemli Akademik Spor Sağlık ve Tıp Bilimleri Dergisi

Ekim - Kasım - Aralık Sayı: 33 Güz Kış Dönemi Yıl: 2019 ID:473 K:459

ISSN Print: 2146-8508 Online 2147-1711

(ISO 18001-OH-0090-13001706 / ISO 14001-EM-0090-13001706 / ISO 9001-QM-0090-13001706 / ISO 10002-CM-0090-13001706) (TRADEMARK)

(2015/04315- 2015-GE-18972)

Same way between age and total food supplements (r: 0,446)

Same directional (r:0,510) between age and all total). Correlation coefficients were found. These floor numbers are statistically significant. All scores increase as age increases. The data obtained from our statistical method study was based on SPSS $(22,0)$ and when parametric test assumptions were fulfilled (Komogorot-Simirnov), the difference between the two averages in independent groups was taken as materiality test, fulay test and konalisation analysis renewal level was 0.05.

\section{DISCUSSION}

There is no doubt that nutrition has an important role in the ability of an athlete to perform well. Athlete nutrition means taking the athlete forward, ensuring that he is successful and giving him the opportunity to play sports in a healthy way. However, the athlete is fed enough and balanced only when he / she receives the nutrients required by his / her sport. According to sports experts; sports protect and improve health. In another study conducted by Abood et al, randomly selected athletes from a women's soccer team and a women's judo team in Florida and their nutritional information levels were measured, and the nutritional information of the athletes was found to be inadequate. It was revealed that the nutritional information of the athletes was for training purposes only.

In a study conducted by Cupisti et al, 60 athlete ladies and 59 sedentary ladies, whose ages ranged from 14-18, were selected and their nutritional information levels measured. In both groups, the daily energy requirement is similar, but generally less than the recommended amount. The results of the study showed that the nutritional information level of the athletes was higher than the other group.

In a study by Douglas, the nutritional information levels of high school athletes were measured and analyzed. A total of 943 athletes participated in the survey. Female athletes were found to be more successful than male athletes.

As a result of this research, it was determined that judoists had sufficient knowledge about nutrition. However, the level of nutrition knowledge can be further increased by directing athletes to nutrition training.

\section{CONCLUSION}

The athletes covered of, $37.87 \%$ were female and $62.12 \%$ were male. The study found no significant difference between the nutritional information levels of male athletes and female athletes. 
International Refereed Academic Journal of Sports, Health and Medical Sciences October - November - December Issue: 33 Fall Winter Semester Year: 2019

Uluslararası Hakemli Akademik Spor Sağlık ve Tıp Bilimleri Dergisi

Ekim - Kasım - Aralık Sayı: 33 Güz Kış Dönemi Yıl: 2019 ID:473 K:459

ISSN Print: 2146-8508 Online 2147-1711

(ISO 18001-OH-0090-13001706 / ISO 14001-EM-0090-13001706 / ISO 9001-QM-0090-13001706 / ISO 10002-CM-0090-13001706) (TRADEMARK)

(2015/04315- 2015-GE-18972)

It is only through balanced, regular and purposeful nutrition that the athlete can achieve a high sporting efficiency. The basic and first condition for proper and beneficial nutrition is the balance between the energy requirement and its requirement.

While the results of the research indicate that judoists take an energy-enhancing nutrient, they do not take energy-enhancing food supplements. Most of the daily energy needs are met by carbohydrates. It is known that taking carbohydrate foods just before training or matches will be beneficial. We can say that more than half of the judoists are in the right practice. They noted that judoists who take energy-boosting nutrients before training or a match take athlete's drinks, vitamin supplements, chocolate and sugary foods.

As a result, wrestlers are in the correct practice in the intake of certain nutrients in the sportsman's nutrition, but they are in the wrong practice in the intake of certain nutrients. This shows that the coaches, who are cited by the athletes as the source of information and the person responsible for nutrition, have sufficient knowledge of athlete nutrition but need to improve it further. For this reason, extensive seminars and courses should be given by the experts in the training of athletes at the national team camp and within the clubs. The publications on athlete nutrition should be delivered to athletes and coaches and they should be informed correctly (Corley-1990).

\section{RECOMMENDATIONS}

1. The daily nutrition levels of men and women judoists should be observed in more detail and associated with judo performance.

2. Weight adjustment practices related to male and female judoists can be associated with performance by taking more detailed measurements.

3. The performance of both male and female judoists in competition after feeding regimes should be related.

4. Nutrition awareness training of athletes should be planned and implemented without being considered separate from the whole society.

5. More research should be done on this subject in different age groups.

6. Supplements of ergogenic substances and vitamins and minerals should not exceed the recommended daily Allowance (RDA) and should be certified by the National Sanitation Foundation (NSF).

\section{REFERANCES}

AINSWORTH, B.E., HASKELL, W.L., WHITT, MC, IRWIN, M.L., SWARTZ, A.M., et al, (2000). Compendium of 
International Refereed Academic Journal of Sports, Health and Medical Sciences October - November - December Issue: 33 Fall Winter Semester Year: 2019

Uluslararası Hakemli Akademik Spor Sağlık ve Tıp Bilimleri Dergisi Ekim - Kasım - Aralık Sayı: 33 Güz Kış Dönemi Yıl: 2019 ID:473 K:459

ISSN Print: 2146-8508 Online 2147-1711

(ISO 18001-OH-0090-13001706 / ISO 14001-EM-0090-13001706 / ISO 9001-QM-0090-13001706 / ISO 10002-CM-0090-13001706) (TRADEMARK)

physical activities: classification of ener-

gy cost of human physical activities. Med

Sci Sports Exerc. 32(9), 498-516

\section{THE AMERICAN DIETETIC ASSOCIA-}

TION, (2009). Position of the American

Dietetic Association, Dietitians of Canada, and the American College ofSports Medicine: Nutrition and Athletic Performance. Journal of The American Dietetic Association. March, pp, 509-527

BAYSAL, A., (2005). Sporda Beslenme. Morpa Kültür Yayınları, İstanbul

BAYSAL, A., (2010). Beslenme. 12. Bask1. Hatipoğlu Yayınları, Ankara.

BISHOP, N.C., GLEESON, M., NICHOLAS, C.W., $A L \dot{I}, A$., (2002). Influence of carbohydrate supplementation on plasma cytokine and neutrophil degranulation responses to highintensity intermittent exercise. Int J Sports Nutr Exerc Metab. 12(2),145-56
BOISSEAU, N., VERA-PEREZ, S., \& POORTMANS, J., (2005). Food and fluid intake in adolescent female judo athletes before competition.Paediatric Exercise Science, 17, 62-71

BURKE, L., (1995). Practical issues in nutrition for athletes. J Sports Sci. 13:S83-S90. Cabral, C.A.C

CABRAL, C.A.C., ROSADO, G.P., SILVA, C.H.O., MARINS, J.C.B., (2006). Diagnosis of the nutritional status of the Weight Lifting Permanent Olympic Team athletes of the Brazilian Olympic Committee (COB). Rev Bras Med Esporte, Vol. 12:6 - Nov/Dez, pp, 308-312

G $\ddot{U} N E S$, , Z., (2005). Spor ve Beslenme, Nobel Yayın Dağıtım,4.Baskı.s1, Ankara

CORLEY, G., DEMAREST-LITCHFORD, M., BAZZARRE, T.L., (1990). Nutrition knowledge and dietary practices. of college coaches. J Am Diet Assoc 1990; 90: 705-9 